The Sustainable City XIV 21

\title{
MOVING TOWARDS SUSTAINABLE AGRICULTURAL LAND MANAGEMENT AND PRACTICES IN KOSOVO
}

\author{
FJOLLË CAKA \\ Institute for Environment and Health, South East European University, North Macedonia
}

\begin{abstract}
Agriculture is one of the sectors contributing to large greenhouse gas emissions, thus impacting ecosystems vitality, public health and climate change. It is also a very climate-sensitive sector, which is expected to face many challenges (especially economic damages) due to climate change impacts, mainly in developing countries. Even though agriculture is considered a national priority for Kosovo's economic development, there are still many prevalent challenges, including agricultural land loss and management (due to urbanization and economic developments), agricultural land contamination and pollution, high dependency on irrigation, old farm buildings and equipment, lack of knowledge on contemporary production techniques, and incompliance with the EU standards. With current agricultural and food production practices being inefficient and resource-consuming, coupled with potential future climate change impacts in the country, it is crucial to move towards more climateresilient and sustainable practices. As Kosovo integrates its development and climate adaptation considerations in policy and technical changes, it is crucial to strengthen the rural, peri-urban and urban linkages towards ensuring food security and increased communities resilience. While climate adaptation require a mixture of capital and behavioural changes, lack thereof may increase adverse impacts on food security, public health, poverty reduction and economic development. Sustainable agriculture and food production practices can contribute to improved livelihoods and local economic development, food security, poverty reduction, social inclusion, health and sustainable and climateresilient city development. In this regard, this paper presents current issues in the agricultural sector (land management and food production practices) and suggests respective recommendations for policy and practice improvements (including protection of agricultural land and its sustainable management, expanded irrigation network, nutrients use and manure management, shift to more climate-resilient produce, promotion of urban agriculture, enhanced institutional support and incentives) towards communities' future sustainable and resilient development in Kosovo.
\end{abstract}

Keywords: sustainable agriculture, climate-resilient agriculture, urban agriculture, sustainable food production practices.

\section{INTRODUCTION}

Agriculture is very climate-sensitive sector [1]. Climate change can impact the amount of land that is farmed, how the farmland is used (e.g. for crops or livestock), type of crop or livestock species (or their respective mixes/breeds alterations), and whether to irrigate or not, depending on countries' specific latitudes [1], [2]. From 1960 to 2000, changes in temperature and $\mathrm{CO}_{2}$ concentrations have caused a net global increase in agricultural GDP from $2 \%$ to $4 \%$, followed by a $3 \%$ to $5 \%$ total change in agricultural production [1]. However, studies show that if temperature increases by $3^{\circ} \mathrm{C}$, farmland losses begin to outweigh the gains [1]. In addition, even though irrigation choices depend on precipitation, temperature increase can also increase the amount of water needed, thus the costs [1]. To reduce potential costs and losses, farmers have to switch to more feasible (temperature and water stress resilient) crops or livestock species. For example, African and South American farmers are more likely to raise sheep and less likely to raise dairy and beef cattle in response to temperature increases [1]. Such changes may be costly on their own (if specific infrastructural arrangements or other interventions have to be done), but may also have adverse impacts on the farmers' revenues out of such products (e.g. if they have to grow crops or livestock that 
do not have a high demand on the market). In this regard, as climate changes, agrarian countries (especially developing ones in the low latitudes) are expected to experience large damages and losses [1], [2].

In addition, agriculture itself contributes to high environmental pressures and climate change impacts through soil degradation (erosion, compaction), energy consumption for onfarm operations, water stress from irrigation and other on-farm water, water pollution and salinization, greenhouse gas (GHG) emissions (from nutrients application, manure spreading and storage, animal housing and grazing), and biodiversity loss [3]. Global resource extraction and processing of materials, fuels and food accounts for around half of the total GHG emissions, and for more than $90 \%$ of biodiversity loss and water stress in the world [3]. According to Kosovo's GHG emissions inventory for the period of 2008-2013, agriculture sector emits $690 \mathrm{Gg} \mathrm{CO}_{2}$ eq., which accounts for $7 \%$ of the total emissions [4]. Agricultural emissions mainly derive from livestock enteric fermentation (digestive processes) and from manure management (around $550 \mathrm{Gg} \mathrm{CO}_{2}$ eq. per year), as well as from land fertilization and burning of biomass (around $150 \mathrm{Gg} \mathrm{CO}_{2}$ eq. per year) [4].

Since agricultural practices have economic and environmental impacts in most of the countries around the world (including Kosovo), moving towards sustainable respective practices is crucial towards the achievement of Sustainable Development Goals (SDGs). Sustainable food and agriculture have great potential in addressing hunger, poverty and sustainability issues through the provision of affordable and nutritious food, strengthening of livelihoods, promotion of inclusive growth, revitalization of rural and urban landscapes, and improvement of environmental performance.

With agriculture being an important (but sensitive) economic sector in Kosovo, itself facing potential future adverse impacts from climate change [5], it is crucial to shift to more sustainable and climate-resilient agricultural policies and food production practices. In this regard, Kosovo has already started environmental and climate change mainstreaming in its agricultural policies, and respective sector strategies and action plans [5], [6]. Furthermore, it has also started applying land use and management policies towards agricultural land protection (from pollution, degradation, and loss/conversion to construction land) and improvement (thus increasing its productivity). However, challenges still remain, as current agriculture and food production/transportation practices in Kosovo remain resourceconsuming and inefficient, contributing to loss of biodiversity, water scarcity, increased GHG emissions and pollution of air, water and soil [3], [7].

This paper analyses prevalent issues in agricultural sector in Kosovo, suggesting respective approaches and measures for embracing more sustainable and climate-resilient practices towards the country's decoupling of economic development from environmental degradation. It is based on literature review for identifying existing agricultural practices in Kosovo, their impact on economy, environment and climate change, and respective institutions' roles and responsibilities. Upon the identification of main issues and challenges, respective recommendations towards making the agricultural sector and food production practices more sustainable and climate-resilient are provided.

\section{BACKGROUND}

\subsection{Agricultural activities, land use and products}

Agriculture is an important and strategic economic activity for Kosovo as well, contributing to its gross domestic product (GDP) by 7\% [8]. It represents income opportunities, especially for rural areas, as urban agriculture is not that prevalent. In 2018, there were 2,942 registered 
agri-businesses, with a total of 13,156 people employed in the sector (marking a $25.9 \%$ increase from the previous year) [8]. Agricultural activities comprised $6.4 \%$ of the country's total economic activities [8].

In 2018, Kosovo's total land used for agriculture was 418,582 ha, out of which $52.12 \%$ were meadows and pastures (including cooperatives), $45 \%$ arable land, $1.84 \%$ fruit plantations, $0.78 \%$ vineyards, $0.24 \%$ gardens, and $0.03 \%$ plant nurseries [8]. Most of the arable land $(81.32 \%)$ is of high quality (1-4 land classes), lying on both the eastern and western plains of the country and along the river valleys [9]. Agricultural land in Kosovo is mainly cultivated for cereal grains $(123,869 \mathrm{ha})$, vegetables $(17,886 \mathrm{ha})$, fruits $(7,992 \mathrm{ha})$, vineyards $(3,272 \mathrm{ha})$ [8]. Around 160 ha of land are used for medical and aromatic plants cultivation, and 179,580 ha are certified for medical plants and wild fruits collection [6]. Main cultivated crops comprise cereal grains $(65 \%$ wheat, $31 \%$ corn, and $4 \%$ oats, barley, rye and others), vegetables (20\% potatoes, $17 \%$ peppers, $16 \%$ beans, $13 \%$ squash, $34 \%$ others), fruits (32\% apples, $23 \%$ plums, $19 \%$ raspberries, $26 \%$ others), vineyards ( $75 \%$ wine grain, 25\% table grain) [8]. Most raised cattle include beefs, goats and chickens [8]. In 2018, agricultural production from crops was 388 million Euros, whereas from livestock 272 million Euros [8].

However, current agricultural production capacities in Kosovo do not fulfil the country's needs, therefore, products' import remains still high [8]. Around $42.3 \%$ of agricultural products were imported from European Union (EU) countries (including Germany, Poland and Italy), 33.6\% from Central European Free Trade Agreement (CEFTA) countries (including Serbia, Macedonia and Albania), and 24.1\% from other countries [8].

\subsection{Agricultural development and land management}

Agricultural development and land management in Kosovo is regulated from laws and Administrative Instructions developed by the Ministry of Agriculture, Forestry and Rural Development (MAFRD), Ministry of Economy and Environment (MEE, previously Ministry of Environment and Spatial Planning - MESP) and other relevant institutions. Law No. 03/L098 on Agriculture and Rural Development (and respective strategy an action plan) aims to develop the agriculture sector (especially in rural areas) in Kosovo, by supporting market competitiveness, land management, economic diversification, local communities development, food quality and sustainable production, in lieu with EU directives [7, p. 1]. Law No. 03/L-016 on Food controls food safety and its contents quality in all food chain levels, whereas Law No. 02/L-75 on Public Health safeguards human health through disease prevention (including food-borne diseases) [7].

Even though at initial stage, progress is also being made in organic agriculture, mainly in the legal aspect (Law No. 04/L-085 on Organic Agriculture corresponding with the EC regulations No. 834/2007 and No. 889/2008) and product certification (through two international certification bodies, one from Albania and one from Greece), following international practices mainly from Croatia, Slovenia, Romania, Bulgaria and Hungary [7]. However, certification costs are high, hence increasing the production cost. In this regard, most of the organic produce is oriented for export to the EU countries (like Austria, Germany and Switzerland) and other neighbouring (Serbia, Macedonia and Montenegro) countries [7].

The MAFRD has supported agricultural development through investments in physical assets of agricultural economies and products processing and trade, farms diversification and business development, and irrigation [8]. It has also supported farmers with agricultural inputs (sapling), agricultural loans and loan guarantees, agricultural sector insurance, and capacity building (awareness raising, trainings, counselling, local action groups, etc.) [7]. It 
has also been stimulating youth engagement in agricultural and other non-agricultural activities (such as agro-tourism) by setting age limits for farm owners when applying for investment subventions and grants, training and access to different information [7]. As a result, women and youth employment in agriculture (especially on organic agriculture collection points) is increasing [7].

Law No. 04/L-040 on Land Regulation mandates the Ministry of Agriculture, Forestry and Rural Development (MAFRD), Kosovo Cadastral Agency (KCA), municipalities and municipal cadastral offices as main responsible institutions for land use regulation [6]. Most $(88 \%)$ of the agricultural land ownership in Kosovo is private and $12 \%$ public (owned by state enterprises and cooperatives, with farms ranging from 500 to 1,500 ha) [5]. Around $93 \%$ of agricultural households own farms smaller than $5 \mathrm{ha}$, with most of them ranging between 2 and 5 ha [7], [8]. Only $1.7 \%$ of the farms are of 10 ha or more [7]. This land fragmentation remains a challenge to feasible food production, collection and transportation processes.

\section{MAIN ISSUES}

Despite many measures undertaken by the local and central level institutions, land (soil) pollution and degradation trend in Kosovo is increasing, especially along the main local and regional streets [6]. Some of the identified main issues in agricultural sector in Kosovo include agricultural land loss to new constructions (due to expansion of urban areas, riverbed extractions, or other roadside developments), poor land management practices (land fragmentation and conversion and lack of comprehensive and functional system for land monitoring), poor agricultural production practices (incompliance with the EU standards due to the lack of knowledge or technologies), high land contamination (due to industrial facilities or complexes, garbage disposal and landfill sites in the proximity), old farm buildings and equipment, absence of manure storage facilities on livestock farms (which is stored in heaps outside barns, close to road drains and along river basins), lack of data, monitoring and management (of the use of pesticide and fertilizers in agricultural land, agricultural pollution's impact on surface water and health impacts), and high dependency on government subsidies and international donor funding [6], [7], [12].

From year 2000-2018, the total urban area in Kosovo has grown by $57 \%$ (a total of $6,000 \mathrm{ha}$ ), mainly to the cost of agricultural land [10] causing a decrease of the total land area used for agricultural purposes by $1.6 \%$ [10]. The arable land area is also very low ( $0.25 \mathrm{ha} /$ person) as compared to that of EU countries ( $0.52 \mathrm{ha} /$ person) [11]. Agricultural land loss to new (illegal) constructions and riverbed excavations causes reduced farmland and green space areas, damage to soil and water resources, industrial pollution, and landfills [5]-[7], [9], [12]. Furthermore, around 10,000 ha of agricultural land (along with around 9,000 residential objects and respective technical infrastructure and 50,000 inhabitants) are threatened from river floods [11].

Kosovo's institutions have already undertaken agricultural land protection measures and municipal inspectorates have started reporting illegal conversions from agricultural to nonagricultural land [7]. Efforts have been made in protection of agricultural land from illegal constructions (especially on qualitative agricultural land, categories 1-4 or other special zones) and supporting agricultural and rural development; therefore a slight increase of land used for agricultural purposes has been noted during the past years (2016-2018) [6], [8], [11].

Even though the transition from traditional family farms to commercial ones is ongoing, land fragmentation is still one of the main issues contributing in low work efficiency, thus causing high production costs [7]. On the other hand, besides private home gardens, urban agriculture or farming (including community gardens or other rooftop and vertical farms) is not that prevalent in Kosovo. Some initiatives for growing urban produce (including 
permaculture activities) have already started, but they remain in a very small scale. A slight increase of such activities has also been noted during the past several months shutdown due to the COVID-19 pandemic.

Furthermore, agricultural land is often used without any criteria or standards due to lack of knowledge on contemporary (production) practices and technologies, old farm buildings and equipment, and lack of inspection [7]. In this regard, land is often degraded beyond repair, which when coupled with soil pollution reduces the quality and quantity of agricultural products and cultures [6].

Usage of pesticides and fertilizers in agriculture contributes towards water pollution as well. Around 19,000 tons of nitrogen is produced from livestock each year, and with improper manure storage and management, much of it leaches into soil and local water bodies [12]. This poses a potential health risk since many rural villages depend on wells and local springs for potable water (due to the lack of access to piped drinking water) [12].

In addition, agriculture in Kosovo is highly dependent on irrigation, but only around 5\% of the total arable land area is irrigated (compared to $20 \%$ in the EU) [11]. Considering Kosovo's water stress and potential water scarcity, increased irrigation remains an ongoing challenge.

The agricultural sector in Kosovo, despite being favorited and considered a national priority for the country's economic development, is still heavily reliant on agricultural loans (provided by many banks and micro-financial institutions) and international financing [7]. Efforts are also being made in compensating farmers from damages caused by low or high temperatures, and rainfall; however, insurance companies still lack expertise in assessing agricultural damages and hesitate in selling agricultural insurance policies (since the risk is systematic, causing huge potential losses) [7].

\section{CONCLUSIONS AND RECOMMENDATIONS}

Kosovo is rich with agricultural land, the majority of which is of high quality. However due to poor land management and agricultural and food production practices, agricultural land continues to be converted to construction land, is degraded beyond repair, and remains contaminated. As such, current agricultural production does not fulfil current population needs, therefore the country is heavily reliant on import. As population grows and demand for food will increase.

With agriculture being a very climate-sensitive sector (and highly dependent on irrigation), future projected temperature increases and precipitation changes in the region will add additional challenges to food security, livelihood opportunities and economic development in Kosovo, especially in rural areas. As such, there will be an increased need for greater agricultural yields, generated using less water, energy and space on land [13].

Climate adaptation requires a mixture of capital and behavioural changing [1]. Promising opportunities provided by climate change shall be used smartly, whereas potential damages should be avoided or reduced [1]. However, if no climate change adaptation measures are undertaken, Kosovo may face negative consequences for food security, public health, poverty reduction and economic development (mainly affecting agriculture, forestry and water resources) [5]. Furthermore, adaptation costs will rise exponentially, if there are no current successful mitigation efforts [5]. Therefore, incorporating climate change considerations in policy and technical changes, as well as increased capital and improved access in the agricultural sector and related food production practices in Kosovo is crucial [2].

In this regard, development policies and climate adaptation should be integrated into one cohesive program for a more progressive development of Kosovo; hence, a holistic and 
systemic approach towards strengthening the urban, peri-urban and rural agricultural linkages towards enhancing livelihoods and food security and resilience is needed.

Adequate agricultural development and land management policies, food production practices, and institutional and donor support can contribute in achieving Kosovo's potential for ensuring enough food supply for its current and estimated population growth [9]. Furthermore, consumption of local produce supports national economic growth and contributes towards reduced associated food transportation costs and GHG emissions. Hence, sustainable agriculture and food production practices should remain a strategic priority towards communities' sustainable and resilient development in Kosovo.

Table 1: Recommendations towards sustainable agriculture and food policies and practices.

\begin{tabular}{|c|c|}
\hline $\begin{array}{l}\text { Science-based } \\
\text { and sustainable } \\
\text { approach }\end{array}$ & $\begin{array}{l}\text { - Investing in data collection, reporting and verification in agriculture } \\
\text { sector [19]. } \\
\text { - Supporting sustainable and healthy food policies and systems } \\
\text { (according to the EU's Farm to Fork Strategy) [3]. } \\
\text { - Integrating ecosystems and their services into decision-making } \\
\text { towards preserving and restoring the natural capital (including } \\
\text { agriculture, fisheries) [3]. } \\
\text { - Undertaking studies on climate adaptation in agriculture (including } \\
\text { what crops to grow, what animals to raise, what inputs to employ) } \\
\text { based on the specific context [1]. } \\
\text { - Sustainable land use planning (protecting agricultural land loss and } \\
\text { degradation from urbanization and other infrastructural projects } \\
\text { through concentrated and compact developments, as well as from river } \\
\text { floods) [9], [11]. } \\
\text { - Revising harvesting, planting and fire policies taking into account } \\
\text { ecological changes due to climate change [1]. } \\
\text { - Shifting to more sustainable and climate resilient/resistant crop } \\
\text { products and livestock breeds (e.g. more resistant to water stress or } \\
\text { salinity, temperature increase, parasites and diseases) [1], [3], [14]. }\end{array}$ \\
\hline $\begin{array}{l}\text { Institutional } \\
\text { support and } \\
\text { incentives }\end{array}$ & $\begin{array}{l}\text { - Provision of low-cost favorable locations for agricultural purposes [9]. } \\
\text { - Investing in water sector infrastructure including dams (for storing } \\
\text { early winter melt for valuable growing season irrigation), levees (for } \\
\text { controlling flooding), and new irrigation canals [1], [9], [11]. } \\
\text { - Promotion of sustainable practices in agriculture, such as precision } \\
\text { agriculture, organic farming, agro-ecology, agro-forestry and stricter } \\
\text { animal welfare standards [3]. } \\
\text { - Supporting urban agriculture initiatives, including community } \\
\text { gardens, green rooftops and facades [15], [16]. } \\
\text { - Developing sustainable farming or food certification schemes (to } \\
\text { encourage commitment in sustainable management and consumption) } \\
\text { [3]. } \\
\text { - Implementation of eco-schemes as rewarding measures on improved } \\
\text { environmental and climate performance, e.g. for farmers managing } \\
\text { and storing carbon in the soil, better management of nutrients for } \\
\text { improved water quality and emissions reductions [3]. }\end{array}$ \\
\hline
\end{tabular}


Table 1: Continued.

\begin{tabular}{|c|c|}
\hline $\begin{array}{l}\text { Sustainable } \\
\text { practices (and } \\
\text { technological } \\
\text { advancements) }\end{array}$ & $\begin{array}{l}\text { - Promotion of low impact development techniques (e.g. natural } \\
\text { drainage by planting trees and deep-rooted crops and implementing } \\
\text { crop rotation) [3]. } \\
\text { - Using architectural innovation (bio domes, double-glazed roofs for } \\
\text { retention of heat, light modular steel frames for rapid expansion and } \\
\text { adaptation, LED lights) and tech-savvy farming techniques (zero } \\
\text { carbon greenhouses, hydroponic systems, geothermal energy, } \\
\text { controlled indoor environment) to improve the environmental } \\
\text { performance of existing and new greenhouses (as the case of the } \\
\text { Westland region in the Netherlands) and bio domes (in the Sustainable } \\
\text { City, a net zero energy community in Dubai, UAE) [13], [20]. } \\
\text { - Integrating renewable energy generation on-site (e.g. installation of } \\
\text { solar thermal systems, photovoltaic panels, wind turbines, biomass } \\
\text { boilers on farms or related buildings) [3]. } \\
\text { - Adopting water saving technology, such as sprinklers and drip } \\
\text { irrigation [1]. } \\
\text { - Investing in insulation and cooling capacities of agriculture related } \\
\text { facilities [1]. }\end{array}$ \\
\hline Management & $\begin{array}{l}\text { - Sustainable farm management (including ecological buffer strips, } \\
\text { landscape planning, energy and water efficiency, and development of } \\
\text { biological corridors around and between farms [14], [18]. } \\
\text { - Soil quality and nutrients use management. } \\
\text { - Grass and grazing management (by reducing it during plant flowering } \\
\text { periods) [14]. } \\
\text { - Rainwater storage and usage management for irrigation or animal } \\
\text { washing/watering [1], [14]. } \\
\text { - Proper animal husbandry and manure management [14]. }\end{array}$ \\
\hline Monitoring & $\begin{array}{l}\text { - Developing a comprehensive agricultural land inventory and } \\
\text { monitoring program [6], [11]. } \\
\text { - Reducing and monitoring the use, risk and environmental impact of } \\
\text { chemical pesticides, fertilizers and antibiotics [3], [6]. } \\
\text { - Using Life Cycle Assessment (LCA) or ecosystem service indicators } \\
\text { (with appropriate metrics for monitoring, measuring and continuously } \\
\text { improving farm environmental performance) [14]. }\end{array}$ \\
\hline $\begin{array}{l}\text { Awareness } \\
\text { raising }\end{array}$ & $\begin{array}{l}\text { - Raising awareness in responsible production and consumption (e.g. } \\
\text { selling products directly from farm shops or local farmer markets, co- } \\
\text { operating with local food processors, hosting farm open days and } \\
\text { guided public tours, allowing gleaning/harvesting leftover crops, } \\
\text { supporting healthy diets and reduced food waste) [3], [12]. } \\
\text { - Reducing the environmental impact of food processing and retail } \\
\text { sectors (by lowering their carbon footprint in transport, storage, } \\
\text { packaging and food waste). }\end{array}$ \\
\hline
\end{tabular}

Agricultural activities/practices that should become more sustainable include sustainable agricultural land use planning and management, soil quality and nutrients use management, crop planning and protection, grass and grazing management, animal husbandry, irrigation 
management, and manure management [14]. Even though agricultural development is crucial for the economic development of rural areas, urban areas can benefit from agricultural developments as well. Community gardens (developed in city parks, underutilized areas, rooftops or vertical spaces) in urban areas can contribute in increased access to affordable and nutritious food; local ecosystem, air quality and public health improvements; urban island effect reductions; healthy eating lifestyle awareness raising; and strengthened community ties and social cohesion [15], [16]. Furthermore, such gardens can also serve for storm-water management through rainwater harvesting and storage.

The European Commission (EC)'s Joint Research Centre (JRC) provides a lot of best environmental management practices, such as techniques, measures and actions that can be taken in sectors of agriculture and food processing towards their environmental performance improvements and impacts minimization [14], [17]. Additional recommendations on sustainable agriculture and food production systems are provided within the new European Green Deal (signed in 2019) and the EC's Sectoral Reference Document (SRD) in Agriculture (2018) [3], [14]. A summary of recommendations for moving towards sustainable agricultural land management and food production practices in Kosovo is provided in Table 1.

\section{REFERENCES}

[1] Mendelsohn, R., The economics of adaptation to climate change in developing countries. Climate Change Economics, 3(2), 1250006, pp. 1-21, 2012.

[2] Mendelsohn, R., The impact of climate change on agriculture in developing countries. Journal of Natural Resources Policy Research, 1(1), pp. 5-19, 2008.

[3] European Commission (EC), Communication from the Commission to the European Parliament, the European Council, the Council, the European Economic and Social Committee and the Committee of the Regions, The European Green Deal, Brussels, pp. 1-24, 2019.

[4] Ministry of Environment and Spatial Planning and Kosovo Environmental Protection Agency (MESP/KEPA), Greenhouse Gas Emissions in Kosovo 2008-2013, Prishtina, pp. 1-29, 2015. (In Albanian.)

[5] Hjortberg, A.S. \& Wingqvist, G.Ö., Kosovo Environment and Climate Analysis. Environmental Economics Unit, University of Gothenburg, Swedish Development Cooperation (Sida), pp. 1-17, 2008.

[6] Ministry of Environment and Spatial Planning and Kosovo Environmental Protection Agency (MESP/KEPA), Annual Report on Environmental Situation in Kosovo for 2017, Prishtina, pp. 1-92, 2017. (In Albanian.)

[7] Ministry of Agriculture, Forestry and Rural Development (MAFRD), Green Report 2018, Prishtina, pp. 1-200, 2018. (In Albanian.)

[8] Ministry of Agriculture, Forestry and Rural Development (MAFRD), Agriculture in Figures and Numbers, Prishtina, pp. 1-23, 2020. (In Albanian.)

[9] Ministry of Environment and Spatial Planning and Institute for Spatial Planning (MESP/ISP), Indicators for Spatial Planning in Kosovo, Prishtina, pp. 1-157, 2017. (In Albanian.)

[10] Ministry of Environmental and Spatial Planning and Institute for Spatial Planning (MESP/ISP), Growth of Urban Areas in Municipalities of Kosovo, Prishtina, pp. 1-42, 2018. (In Albanian.)

[11] Ministry of Environmental and Spatial Planning and Institute for Spatial Planning (MESP/ISP), Draft Zoning Map of Kosovo 2020-2028+, Prishtina, pp. 1-144, 2019. (In Albanian.) 
[12] The World Bank, Country Environmental Analysis, Washington, DC, pp. 1-100, 2013.

[13] Walsh, N.P., How the Dutch use architecture to feed the world. ArchDaily, www.archdaily.com/932301/how-the-dutch-use-architecture-to-feed-the-world. Accessed on: 10 Jun. 2020.

[14] Antonopoulos, I. et al., Best Environmental Management Practice for the Agriculture Sector: Crop and Animal Production, European Commission (EC), Joint Research Centre, pp. 1-628, 2018.

[15] Ferreira, A.J.D., Guilherme, R.I.M.M. \& Ferreira, C.S.S., Urban agriculture: A tool towards more resilient urban communities? Current Opinion in Environmental Science and Health, 5, pp. 93-97, 2018.

[16] Pearson, L.J., Pearson, L. \& Pearson, C.J., Sustainable urban agriculture: Stocktake and opportunities. International Journal of Agricultural Sustainability, 8(1-2), pp. 719, 2010. DOI: 10.3763/ijas.2009.0468.

[17] Sustainable Urban Planning, George Washington University (SUP/GWU), Ballston 21. Re-Imagining the Ballston Sector Plan for the 21st Century, Arlington, VA, pp. 1$25,2018$.

[18] Scown, M.W., Winkler, K.J. \& Nicholas, K.A., Aligning research with policy and practice for sustainable agricultural land systems in Europe. Proceedings of the National Academy of Sciences, 116(11), pp. 4911-4916, 2019.

[19] Wendling, Z.A. et al., 2020 Environmental Performance Index, Yale Center for Environmental Law and Policy: New Haven, CT. https://epi.yale.edu/. Accessed on: 10 Jun. 2020.

[20] Diamond Developers, The Sustainable City, Dubai, United Arab Emirates (UAE), www.thesustainablecity.ae/. Accessed on: 10 Jun. 2020. 